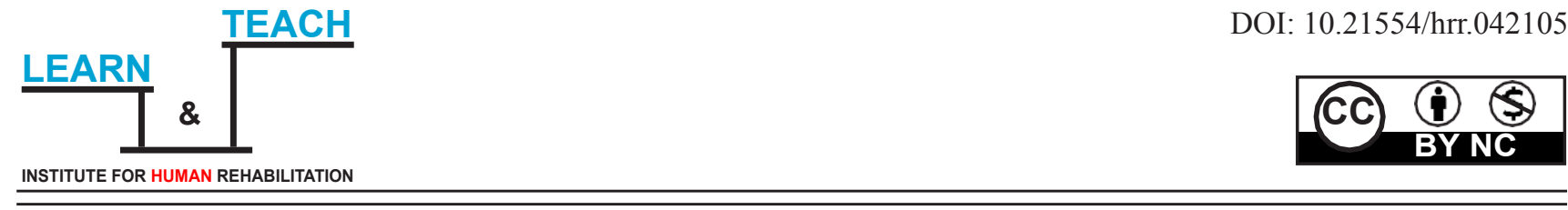

\title{
LEADING DISEASES IN DENTAL PROTECTION OF CHILDREN AND YOUTH IN HERZEGOVINA-NERETVA CANTON IN 2008 AND 2013
}

Original scientific paper

\author{
Nermin Suljkanovic ${ }^{1}$, Dzenan Balic ${ }^{2}$, Nadina Begic ${ }^{1}$ \\ ${ }^{1}$ Doboj Istok Health Center, Doboj Istok, Bosnia and Herzegovina \\ ${ }^{2}$ Mostar Health Center, Mostar, Bosnia and Herzegovina
}

Received: $2021 / 1 / 12$

Accepted: 2021/3/19

\begin{abstract}
The purpose of this paper is to detect the leading diseases diagnosed in dental care, for the population 0-6 years and 07-18 years of age for the Herzegovina-Neretva Canton in 2008 and 2013, to compare the results for those two years, to determine trends, individual diseases, and comparing the obtained results with the results for the territory of the Federation of $B \& H$. During the preparation of this paper, the data collected and published in its reports by the Institute of Public Health of the Federation of Bosnia and Herzegovina were used. Dental caries / K02 / takes the first place on the list of diseases in the field of dental activity, in all age groups. Diseases of the pulp and periapical tissue / K04 /, which most often occur as a result of caries, take second place on the list of diseases in all age groups. It is necessary to work on increasing the number of public healthcare of specialist teams of preventive and pediatric dentistry in the area of HNK, as well as increasing the number of dental care points, where children and youth would receive the service. Further work is needed to improve the state of oral health and the population through.
\end{abstract}

Keywords: Caries, pulp, periapical tissue, oral health

\section{INTRODUCTION}

Health and well-being is the aspiration and need of all people and one of the greatest challenges of the 21 st century. The answer to how to preserve it, lies in recognizing the causes that affect health disorders. However, the economic and social crisis, demographic and epidemiological changes, as well as public health threats from the environment represent a major challenge to preserve and improve the health of the population as stated on the website of the FB\&H Institute of Public Health in the paper (Institute of Public Health of FB\&H, 2013, p. 103).

Oral health is an important component of overall health, according to Smajkic et al. (2013, p. 256).
Before discussing "oral health", it is important to define what health is. However, this is not easy at all and there have been many such attempts. One of the most frequently cited definitions is the one formulated by the World Health Organization in 1958: "Health is a state of complete physical, mental and social well-being and not merely the absence of disease or infirmity."

According to Koch and Poulsen (2005, pp. 21-22; 31), the World Health Organization has defined oral health as a condition of healthy and properly functioning dental and other oral structures, with the absence of dental fear and anxiety.

\section{Correspondence to:}

Nermin Suljkanovic Dr. med. dent. Specialist Pediatric Dentistry, Doboj Istok Health Center, Doboj Istok, Bosnia and Herzegovina.

Doboj Istok, Bosnia and Herzegovina

E-mail: nermin_suljkanovic@hotmail.com 
In his paper, Ivankovic (2004, pp. 55-56) says that Caries dentis, dental caries and its consequences are the most widespread diseases of modern civilization.

According to epidemiological research by many authors in the world, which includes research in this area, dental caries has been found in $97-100 \%$ of the population, so it is rightly considered one of the most widespread diseases of modern civilization. The WHO has published in its publications a large number of data on the prevalence of caries and its programs for its remediation, which have been followed by many countries with their national programs.

According to Stojanovic and Krunic (2006, p. 229) caries is one of the most common oral diseases, not only in children and adolescents, but also in all age groups. In the paper of Markovic et al. (2013, pp.108116) explain that the World Health Organization (WHO) provides a specific methodology for collecting epidemiological data on oral health parameters, through basic research, with a clear goal to provide a systematic approach to collecting and reporting on the state of oral diseases, to ensure that these data are comparable to other national surveys.

Zukanovic and Ganibegovic (2007, pp. 193-204) claim that in all developed countries, the prevalence of caries in all age groups has significantly decreased in recent years. Dental care, based on a well-organized and guided health policy, has enabled the application of massive individual preventive measures, which in many countries has resulted in a large reduction in the prevalence of oral diseases. And the oral health of all age groups in Bosnia and Herzegovina $(\mathrm{B} \& \mathrm{H})$ is among the worst in Europe.

There is still no prevention program to be implemented as part of the official health policy in the country. The main reasons for the current situation are the lack of any national prevention program, curatively oriented dental policy, poor socio-economic condition of the population and changes in living conditions during and after the war. Porovic etal.(2014,pp.97-101) state that apparently dental caries is a major health problem today. Complications of caries, such as pain and others, have an impact on mental development, general health and quality of life.

\section{AIMS}

The purpose of this paper is to detect the leading diseases diagnosed in dental care, for the population 0-6 years and 07-18 years of age for the HerzegovinaNeretva Canton in 2008 and 2013, to compare the results for those two years, to determine trends, individual diseases, and comparing the obtained results with the results for the territory of the Federation of $\mathrm{B} \& \mathrm{H}$.

\section{METHODS}

During the preparation of this paper, the data collected and published in its reports by the Institute of Public Health of the Federation of Bosnia and Herzegovina (public heathcare sector) were used,

- Health Statistical Yearbooks of the Federation of Bosnia and Herzegovina for 2008 and 2013 (11; 26; $59 ; 60)$

- Health status of the population and health care in 2008 and $2013(36 ; 47 ; 89)$

\section{RESULTS}

Estimated total population on 30.06. in 2008, the Federation of Bosnia and Herzegovina (FB\&H) had a total population of 2,327,195, and the HerzegovinaNeretva Canton (HNK) had a total population of 226,632, according to the Institute of Public Health of the Federation of $\mathrm{B} \& \mathrm{H}(11 ; 26 ; 59 ; 60)$, which accounted for $9.74 \%$ of the FB\&H.

Estimated total population on 30.06. in 2013, there were a total of 2,337,200 inhabitants in the FB\&H, and in the Herzegovina-Neretva Canton (HNK) there were a total of 224,388 inhabitants according to the data of the Institute of Public Health of the Federation of B\&H (Zdravstveno statisticki godisnjak, 2014, pp. 36; 47; 89), which was $9.6 \% \mathrm{FB} \& \mathrm{H}$.

Table 1. Estimation of the total population in 2008 and 2013 in FB\&H and HNK in the total number and by age groups

FB\&H HNK

\begin{tabular}{ccccccccc}
\multirow{2}{*}{ Year } & \multicolumn{10}{c}{$\mathbf{0 - 1 4}$} & $\mathbf{1 5 - 6 4}$ & $\mathbf{6 5 +}$ & Total & $\mathbf{0 - 1 4}$ & $\mathbf{1 5 - 6 4}$ & $\mathbf{6 5}^{+}$ \\
\cline { 2 - 9 } & Total & $\mathbf{0 - 1 4}$ & 1579.720 & 327.623 & 226.632 & 37.473 & 150.802 & 38.357 \\
\hline 2008 & 2.327 .195 & 419.852 & 1.605 .813 & 331.277 & 224.388 & 35.935 & 150.146 & 38.307 \\
\hline
\end{tabular}

In 2008 , there were a total of 476 doctors of dentistry in public health care sector (of which 137 specialists) employed in the public health care of the FB\&H, which was a rate of 2.0 dentists per 10,000 inhabitants. Dental care was performed in FB\&H at 226 points and 438 dental chairs. In the same year, the number of dentists employed in the health care of the HNK was 56 (20 specialists), which was a rate of 2.5 dentists per 10,000 inhabitants. Dental care at HNK was performed at 31 points, ie 38 dental chairs, according to the data of the Institute of Public Health of the Federation of B\&H (Zdravstveno statisticki godisnjak, 2009, pp. $11 ; 26 ; 59 ; 60)$. 
On the other hand, in 2013, the number of dentists employed in the FB\&H public health care system was 576 (of that number, 208 specialists), which is a rate of 2.5 dentists per 10,000 inhabitants. Public dental care was performed in $\mathrm{FB} \& \mathrm{H}$ at 226 points and 438 dental chairs. The number of dentists employed in the public health care of HNK was 53 (of which 18 specialists), which is the rate of 2.4 dentists per 10,000 inhabitants. Public dental care at HNK was performed at 33 points, ie 38 dental chairs, according to the data of the Institute of Public Health of the Federation of B\&H (Zdravstveno statisticki godisnjak, 2009, pp. 11; $26 ; 59 ; 60)$.

Table 2. Dentists employed in health care, number of points and dental chairs in FB\&H and HNK in 2008 and 2013

\begin{tabular}{|c|c|c|c|c|c|c|c|c|c|c|}
\hline \multirow[b]{2}{*}{ Year } & \multicolumn{5}{|c|}{ FB\&H } & \multicolumn{5}{|c|}{ HNK } \\
\hline & 高 & 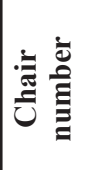 & 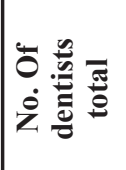 & 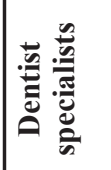 & 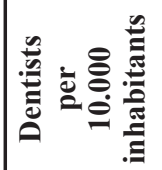 & 音 & 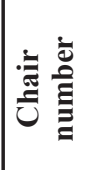 & 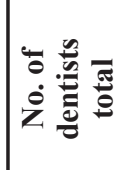 & 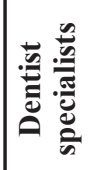 & : \\
\hline 2008 & 226 & 438 & 476 & 137 & 2.0 & 31 & 38 & 56 & 20 & 2.5 \\
\hline 2013 & 226 & 438 & 576 & 208 & 2.5 & 33 & 38 & 53 & 18 & 2.4 \\
\hline
\end{tabular}

The average number of examinations in the dental service in the $\mathrm{FB} \& \mathrm{H}$ was 0.5 per capita, and in the area of HNK this number was 0.3 per capita. In the same year, in FB\&H there were 4528 inhabitants per one public dentist, and in HNK there were a total of 4882 inhabitants per one public dentist, according to the data of the Institute of Public Health of the Federation of B\&H (Zdravstveno statisticki godisnjak, 2014, pp. 36; 47 ; 89). In 2013, in both the FB\&H and the HNK, the average number of dental visits per capita was 0.5 . The number of inhabitants per one public dentist in 2013 in FB\&H was 4401, and in HNK 4774.

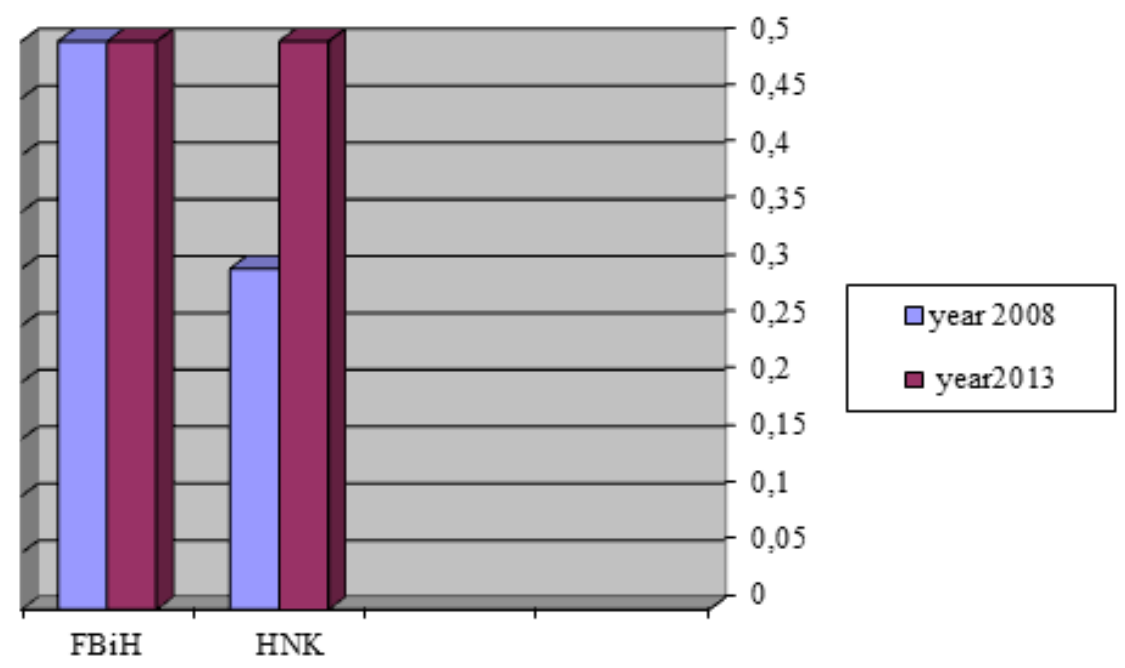

Graph 1. Average number of examinations per capita in dental activity in FB\&H and HNK, for 2008 and 2013. 


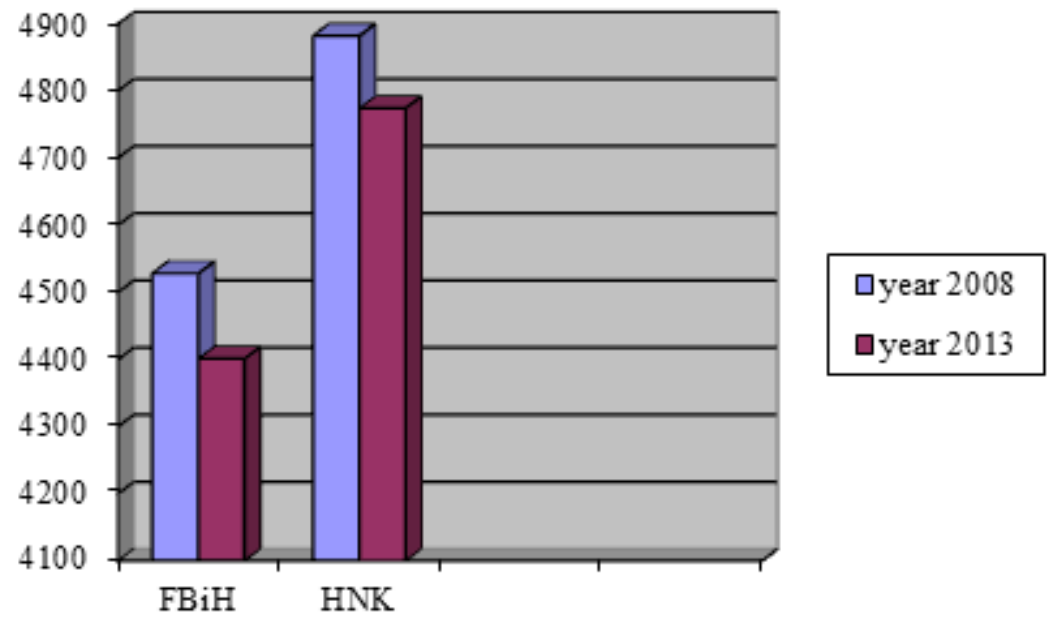

Graph 2. Number of inhabitants per one dentist in FB\&H and HNK for 2008 and 2013

According to the data of the Institute of Public Health of the Federation of $\mathrm{B} \& \mathrm{H}$ (Zdravstveno statisticki godisnjak, 2009, 11; 26; 59; 60) diseases, conditions and injuries identified in the dental activity for the population $0-6$ years and $07-18$ years of age in the HNK and FB\&H in 2008 are shown in table No.3, and in 2013 they are shown in table No. 4.

Table 3. Diseases diagnosed in the dental activity in the areas of $H N K$ and FB\&H in 2008

\begin{tabular}{|c|c|c|c|c|c|c|c|c|c|c|c|c|}
\hline \multirow{3}{*}{ Diseases, conditions and injuries $10 \mathrm{MKB}$} & \multicolumn{6}{|c|}{ HNK } & \multicolumn{6}{|c|}{ FB\&H } \\
\hline & \multicolumn{3}{|c|}{$0-6$ years } & \multicolumn{3}{|c|}{ 07-18 years } & \multicolumn{3}{|c|}{ 0-6 years } & \multicolumn{3}{|c|}{ 07-18 years } \\
\hline & 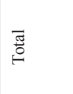 & 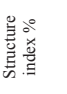 & 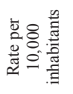 & $\underset{0}{\stackrel{5}{0}}$ & 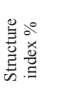 & 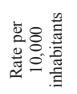 & 嵒 & 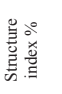 & 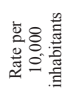 & $\stackrel{\text { हूँ }}{\circ}$ & 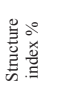 & 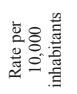 \\
\hline $\begin{array}{l}\text { Malignant neoplasms of the lips and oral cavity } \\
\text { (C00-C08) }\end{array}$ & 0 & 0 & 0 & 0 & 0 & 0 & 0 & 0 & 0 & 3 & 0 & 0 \\
\hline $\begin{array}{l}\text { Malignant neoplasms of the lips and oral cavity } \\
\text { (K00) }\end{array}$ & 82 & 6 & 45 & 743 & 4.4 & 167 & 1.379 & 3.3 & 74 & 8.456 & 2.6 & 185 \\
\hline $\begin{array}{l}\text { Malignant neoplasms of the lips and oral cavity } \\
\text { (K01) }\end{array}$ & 3 & 0.2 & 2 & 14 & 0,1 & 3 & 613 & 1.5 & 33 & 4773 & 1.5 & 105 \\
\hline Dental caries (K02) & 700 & 50.4 & 386 & 8.258 & 48.4 & 1.860 & 17.564 & 42.3 & 943 & 140.521 & 42,8 & 3.081 \\
\hline $\begin{array}{l}\text { Malignant neoplasms of the lips and oral cavity } \\
\text { (K03) }\end{array}$ & 12 & 0.9 & 7 & 467 & 2.7 & 105 & 2.486 & 6 & 134 & 18.642 & 5.7 & 409 \\
\hline Dental pulp and periapical tissue diseases (K04) & 384 & 27,7 & 211 & 6.465 & 37.9 & 1.455 & 12.447 & 30 & 669 & 93.509 & 28.6 & 2.050 \\
\hline Gingivitis and periodontal diseases (K05) & 110 & 7.9 & 60 & 357 & 2.1 & 80 & 2.369 & 5.7 & 127 & 12.523 & 3.8 & 275 \\
\hline $\begin{array}{l}\text { Other disorders of the gingiva and alveolar arch } \\
\text { (K06) }\end{array}$ & 0 & 0 & 0 & 144 & 0.8 & 32 & 174 & 0.4 & 9 & 1.476 & 0.4 & 32 \\
\hline $\begin{array}{l}\text { Dentofacial anomalies / including malocclusion } \\
\text { (K07) }\end{array}$ & 2 & 0.1 & 1 & 183 & 1.1 & 41 & 1.124 & 2.7 & 60 & 32.167 & 9.8 & 705 \\
\hline $\begin{array}{l}\text { Other disorders of teeth and supporting structures } \\
\text { (K08) }\end{array}$ & 3 & 0.2 & 2 & 203 & 1.2 & 46 & 1.106 & 2.7 & 59 & 7.221 & 2.2 & 158 \\
\hline Oral cysts not elsewhere classified (K09) & 0 & 0 & 0 & 0 & 0 & 0 & 146 & 0.4 & 8 & 347 & 0.1 & 8 \\
\hline Other diseases of the jaw (K10) & 70 & 5 & 39 & 153 & 0.9 & 34 & 1.059 & 2.6 & 57 & 6.511 & 2 & 143 \\
\hline Diseases of the salivary glands (K11) & 0 & 0 & 0 & 1 & 0 & 0 & 22 & 0 & 1 & 76 & 0 & 2 \\
\hline Stomatitis and related lesions (K12) & 21 & 1.5 & 11 & 76 & 0.4 & 17 & 864 & 2.1 & 46 & 1.462 & 0.4 & 32 \\
\hline $\begin{array}{l}\text { Other diseases of lips and mucous membranes of oral } \\
\text { cavity (K13) }\end{array}$ & 0 & 0 & 0 & 7 & 0 & 2 & 102 & 0.2 & 5 & 486 & 0.1 & 11 \\
\hline Diseases of the tongue (K14) & 0 & 0 & 0 & 2 & 0 & 0 & 21 & 0 & 1 & 81 & 0 & 2 \\
\hline $\begin{array}{l}\text { Face and oral cavity injuries (S00-S09, T00-T04, } \\
\text { T20, T90) }\end{array}$ & 1 & 0.1 & 1 & 1 & 0 & 0 & 41 & 0.1 & 2 & 107 & 0 & 2 \\
\hline TOTAL & 1388 & 100 & 765 & 17.074 & 100 & 3.842 & 41.517 & 100 & 2.229 & 328.361 & 100 & 7.199 \\
\hline
\end{tabular}


Table 4. Diseases diagnosed in the dental activity in the areas of HNK and FB\&H in 2013

\begin{tabular}{|c|c|c|c|c|c|c|c|c|c|c|c|c|}
\hline \multirow{3}{*}{ Diseases, conditions and injuries 10 MKB } & \multicolumn{6}{|c|}{ HNK } & \multicolumn{6}{|c|}{ FB\&H } \\
\hline & \multicolumn{3}{|c|}{$0-6$ years } & \multicolumn{3}{|c|}{ 07-18 years } & \multicolumn{3}{|c|}{$0-6$ years } & \multicolumn{3}{|c|}{$07-18$ years } \\
\hline & 票 & 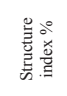 & 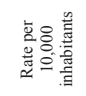 & 嵒 & 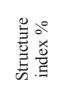 & 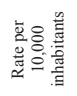 & 嵒 & 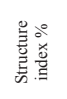 & 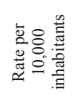 & $\underset{\square}{\vec{g}}$ & 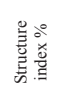 & 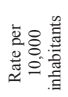 \\
\hline $\begin{array}{l}\text { Malignant neoplasms of the lips and oral cavity } \\
\text { (C00-C08) }\end{array}$ & 0 & 0 & 0 & 0 & 0 & 0 & 0 & 0 & 0 & 3 & 0 & 0 \\
\hline $\begin{array}{l}\text { Malignant neoplasms of the lips and oral cavity } \\
(\mathrm{K} 00)\end{array}$ & 22 & 1.9 & 12 & 403 & 1.9 & 92 & 1.810 & 5 & 91 & 9.762 & 3.3 & 213 \\
\hline $\begin{array}{l}\text { Malignant neoplasms of the lips and oral cavity } \\
\text { (K01) }\end{array}$ & 12 & 1 & 6 & 77 & 0.4 & 18 & 532 & 1.5 & 27 & 3.752 & 1.3 & 213 \\
\hline Dental caries (K02) & 476 & 40.1 & 250 & 9.843 & 46 & 2.238 & 18.546 & 51.5 & 934 & 131.514 & 43,9 & 82 \\
\hline $\begin{array}{l}\text { Malignant neoplasms of the lips and oral cavity } \\
\text { (K03) }\end{array}$ & 9 & 0,8 & 5 & 1.258 & 6 & 292 & 1.701 & 4.7 & 86 & 13.620 & 4.5 & 2.871 \\
\hline Dental pulp and periapical tissue diseases (K04) & 580 & 48.9 & 304 & 6.015 & 28.1 & 1.368 & 9.236 & 25.6 & 465 & 76.119 & 25.4 & 297 \\
\hline Gingivitis and periodontal diseases (K05) & 17 & 1.4 & 9 & 763 & 3.6 & 173 & 1.644 & 4.6 & 83 & 14.362 & 4.8 & 1.662 \\
\hline $\begin{array}{l}\text { Other disorders of the gingiva and alveolar arch } \\
\text { (K06) }\end{array}$ & 4 & 0.3 & 2 & 52 & 0.2 & 12 & 9 & 0.3 & 5 & 1.540 & 0.5 & 34 \\
\hline $\begin{array}{l}\text { Dentofacial anomalies / including malocclusion } \\
\text { (K07) }\end{array}$ & 8 & 0.7 & 4 & 2.505 & 11.7 & 570 & 821 & 2.3 & 41 & 38.505 & 12.8 & 841 \\
\hline $\begin{array}{l}\text { Other disorders of teeth and supporting structures } \\
\text { (K08) }\end{array}$ & 3 & 0.3 & 2 & 209 & 1 & 48 & 344 & 1 & 17 & 4.909 & 1.6 & 107 \\
\hline Oral cysts not elsewhere classified (K09) & 6 & 0.5 & 3 & 4 & 0 & 1 & 9 & 0 & 0 & 269 & 0.1 & 6 \\
\hline Other diseases of the jaw (K10) & 6 & 0.5 & 3 & 24 & 0.1 & 5 & 838 & 2.3 & 42 & 3.160 & 1.2 & 79 \\
\hline Diseases of the salivary glands (K11) & 0 & 0 & 0 & 2 & 0 & 0 & 10 & 0 & 1 & 59 & 0 & 1 \\
\hline Stomatitis and related lesions (K12) & 1 & 0.1 & 0 & 86 & 0.4 & 20 & 269 & 0.7 & 14 & 995 & 0.3 & 22 \\
\hline $\begin{array}{l}\text { Other diseases of lips and mucous membranes of } \\
\text { oral cavity (K13) }\end{array}$ & 0 & 0 & 0 & 22 & 0.1 & 5 & 80 & 0.2 & 4 & 456 & 0.2 & 10 \\
\hline Diseases of the tongue (K14) & 1 & 0.1 & 1 & 4 & 0 & 1 & 8 & 0 & 0 & 36 & 0 & 1 \\
\hline $\begin{array}{l}\text { Face and oral cavity injuries (S00-S09, T00-T04, } \\
\text { T20, T90) }\end{array}$ & 42 & 3.5 & 22 & 88 & 0.4 & 20 & 99 & 0.3 & 5 & 248 & 0.1 & 5 \\
\hline TOTAL & 1.187 & 100 & 21.382 & 21.382 & 100 & 4.862 & 36.038 & 100 & 1.814 & 299.756 & 100 & 6.544 \\
\hline
\end{tabular}

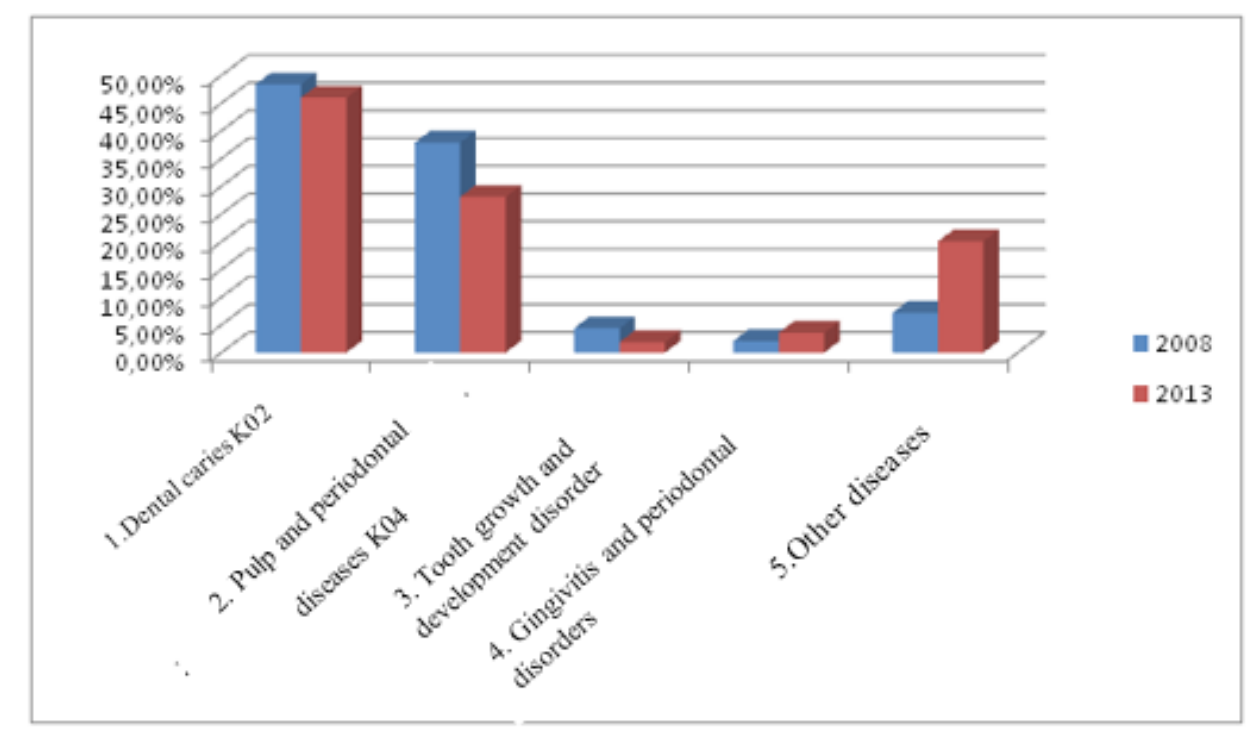

Graph 3. Leading diseases in dental care at HNK in children aged 0-6 in 2008 and 2013 


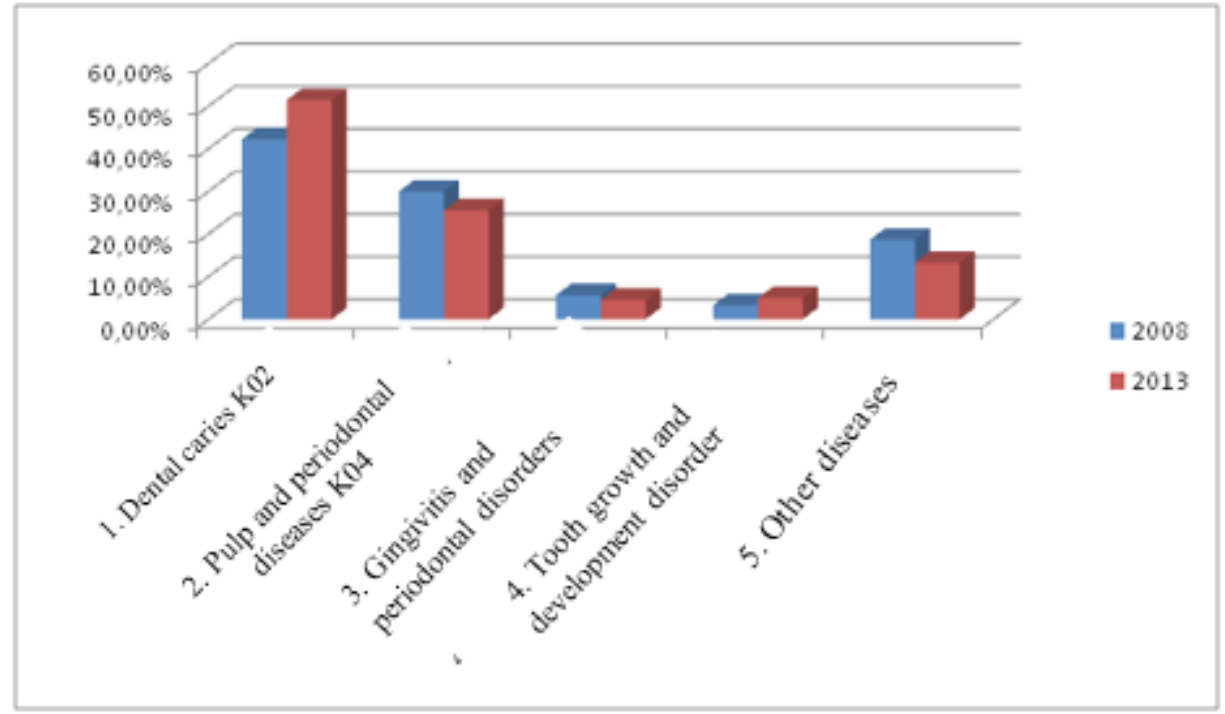

Graph 4. Leading diseases in dental care in FB\&H in children aged 0-6 in 2008 and 2013

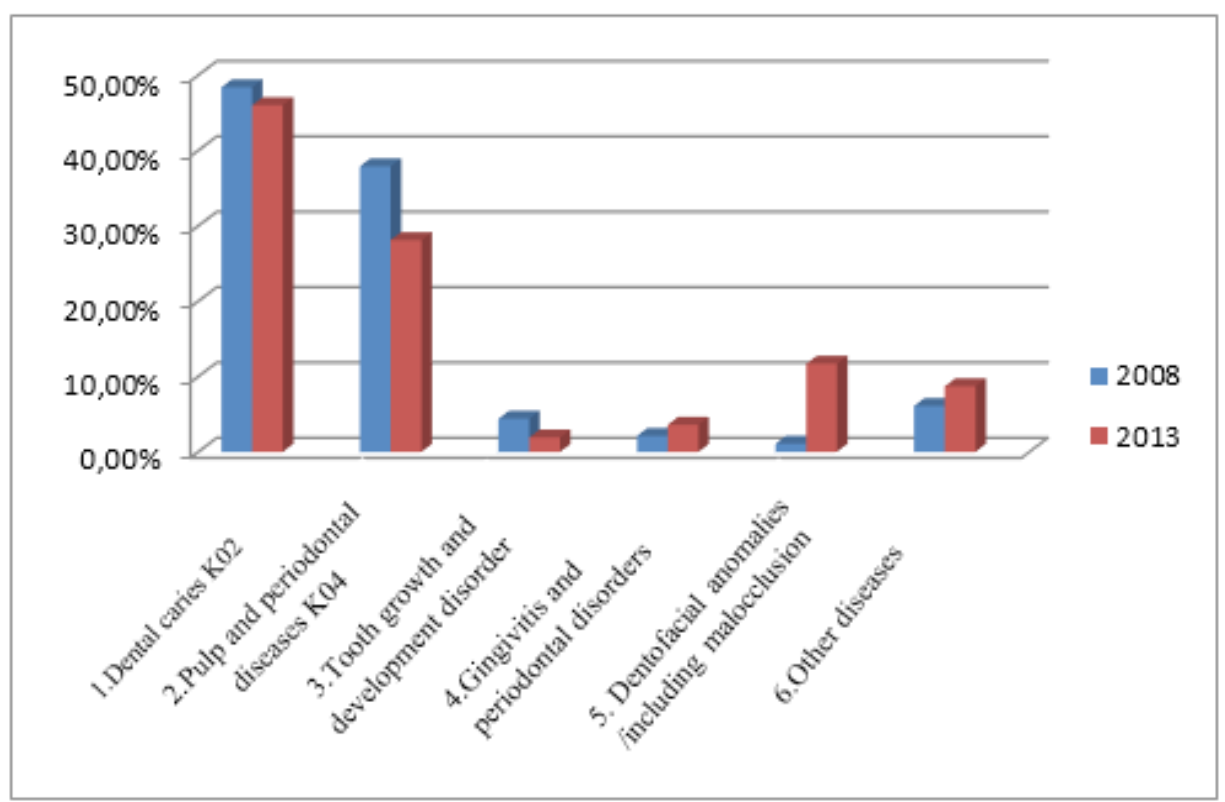

Graph 5. Leading diseases in dental care at HNK among young people aged 7-18 in 2008 and 2013

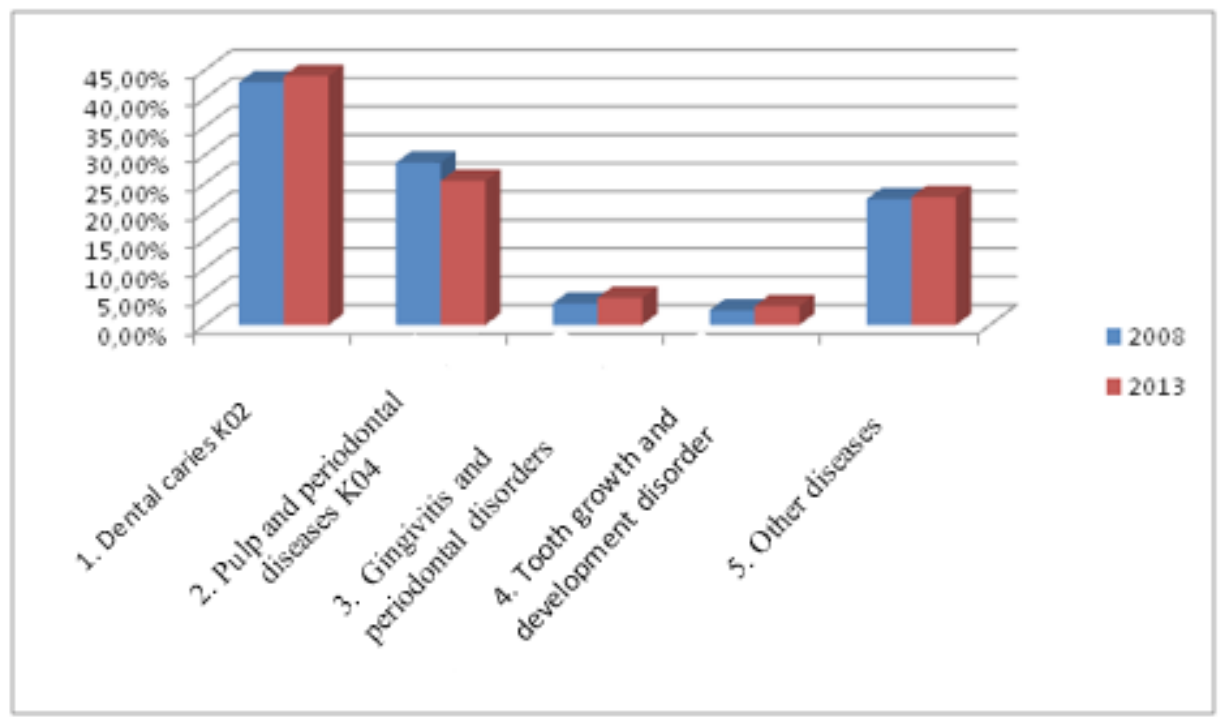

Graph 6. Leading diseases in dental care in FB\&H among youth aged 7-18 in 2008 and 2013 


\section{DISSCUSION}

Dental caries / K02 / takes the first place on the list of diseases in the field of dental activity, in all age groups. In 2008, in the area of HNK, the total percentage of caries in 2008 in children aged 0-6 years, who were examined in dental care points, was $50.4 \%$. This percentage is significantly higher than the percentage of caries in the entire $\mathrm{FB} \& \mathrm{H}$, for the same target group, which was $42.3 \%$. In children aged $7-18$, in the same year, the percentage of caries in the HNK was slightly lower and amounted to $48.4 \%$, which is again higher than in the FB\&H, where the percentage was $42.8 \%$.

In 2013, in HNK, for children aged 0-6, the percentage of caries decreased significantly compared to 2008, and amounted to $40.1 \%$, however, in the FB\&H we have a significant increase in caries in which it amounts to $51.5 \%$. In children aged 7-18 in the area of HNK, we have a slight decrease compared to 2008 , and the percentage of caries is $46 \%$. In the FB\&H we have a percentage of $43.9 \%$ percent of caries, which is less than in the HNK.

Diseases of the pulp and periapical tissue / K04 /, which most often occur as a result of caries, take second place on the list of diseases in all age groups.

In the area of HNK, in 2008, for the age group 0-6, we had a percentage of pulpal diseases of $27.7 \%$. However, already in 2013, we had a significant increase in the percentage of pulp diseases, which amounted to 48.9\%. In 2008, the percentage of pulpitis in HNK was lower compared to FB\&H (30\%). In 2013, we have an increase in the number of pulpitis compared to FB\&H $(25.6 \%)$, and at the same time there is a visible trend of decreasing pulpitis in FB\&H, compared to 2008.

\section{REFERENCES}

Ivankovic, A. Stomatologija za medicinare. (2004). Mostar: Medicinski fakultet Sveucilista u Mostaru,55-56.

Koch, G., \& Poulsen, S. (2005). Pedodoncija-klinicki pristup. Jastrebarsko: Naklada Slap, 21-22;31.

Markovic, N., Arslanagic Muratbegovic, A., Kobaslija, S., Bajric, E., Selimovic-Dragas, M. \& Huseinbegovic, A. (2013). Cariees prevalence of children and adolescents in Bosnia and Herzegovina. Acta Medica Academica, 42(2), 108-116.

Porovic, S., Koradzic-Zuban, S., Spahic-Dizdarevic, M., Brkanic, B., Brankovic. S., \& Cilovic-Lagarija, S. (2014). Evaluation of oral health in 12-year old children int he Vogosca municipality the Sarajevo Canton. Stomatological review, $3(2), 97-101$.

Smajkic, A. et al. (2013). Organizacija i praksa obiteljskel porodicne medicine: Sarajevo, 256.

Stojanovic, N., \& Krunic, J. (2006). Caries prevalence in adolescents in Eastern Bosnia-Foca municipality. Serbian Dental J, 53, p.229.
In 2008 , in the age group of 7-18 years, in the area of HNK, the percentage of pulp diseases was $37.9 \%$, which is higher compared to FB\&H $(28.6 \%)$, but less compared to 2013 (28.1\%). The number of pulp diseases in 2013 was lower in the FB\&H compared to the HNK, and amounted to $25.4 \%$.

The morbidity list changes further depending on age groups. In the HNK in the age group 0-6 years, ginivitis and periodontal diseases are in third place, amounting to $7.9 \%$, while in 2013 , injuries of the face and oral cavity were in third place with $3.5 \%$. In the group of $7-18$ years, in third place in 2008 were disorders of tooth development and growth with $4.4 \%$. In 2013, in the age group 07-18 years, we have a significant increase in dentofacial anomalies (K07), whose percentage is $11.7 \%$, in contrast to 2008 where this percentage was $1.1 \%$. Dentofacial anomalies are on the third place of the disease in the whole FB\&H, where in 2008 they amounted to $9.8 \%$, and in 2013 to $12.8 \%$.

\section{CONSLUSION}

Further work is needed to improve the state of oral health and the population through: caries prevention programs, education and health education of preschool, school children and youth in schools and kindergartens, increasing the number of targeted and control examinations of the oral cavity which would timely register and rehabilitate in the age group of school children and youth. It is also necessary to work on increasing the number of specialist teams of preventive and pediatric dentistry in the area of HNK, as well as increasing the number of dental care points, where children and youth would receive the service.

Zukanovic, A., \& Ganibegovic, M. (2007). Preventive dentistry in Bosnian private dental Practises. Acta Stomatol Croat., 41(3), 193-204.

Zdravstveno stanje stanovnistva i zdravstvena zastita 2008. godine. (2009). Institute of Public Health of the FB\&H, Sarajevo, 60, www.zzjzbih.ba.

Zdravstveno statisticki godisnjak Federacije Bosne i Hercegovine 2008. (2009). Institute of Public Health of the FB\&H, Sarajevo, 11; 26; 59; 60; www.zzjzfbih.ba.

Zdravstveno stanje stanovnistva i zdravstvena zastita 2013. godine. (2014). Institute of Public Health of the FB\&H, Sarajevo, 5, https://www.zzjzfbih.ba/wp-content/uploads/2018/10/ Zdravstveno-2017.pdf.

Zdravstveno statisticki godisnjak Federacije Bosne i Hercegovine 2013. (2014). Institute of Public Health of the F B\&H, Sarajevo, 36; 47; 89; www.zzjzfbih.ba. 